\title{
AtÉ os OSSOS: ESCAVANDO O ÚlTIMO ROMANCE De Graciliano Ramos
}

\author{
To the bone: digging out the last novel \\ of Graciliano Ramos
}

\author{
Gabriela Kvacek Betella*
}

\begin{abstract}
RESUMO
Partindo do conjunto no qual se destaca Vidas Secas (1938), é possível estabelecer parâmetros que fazem da obra de Graciliano Ramos uma superação do realismo graças ao alcance da representação e à qualidade do tratamento formal que o próprio autor desejava, imbuído da tradição literária brasileira e universal, e cujo resultado a crítica de Antonio Candido, hábil em considerar a crítica anterior, localiza com precisão. Percorrendo fatos que pontuam a criação e a recepção de Vidas Secas (incluindo a produção do filme de Nelson Pereira dos Santos, de 1963), este trabalho constitui um preâmbulo para análises que levem em conta a coerência de Graciliano Ramos com recursos expressivos utilizados pelos praticantes americanos e europeus de uma literatura empenhada na adequação da expressão de contrastes e na reformulação do chamado regionalismo.
\end{abstract}

Palavras-chave: Graciliano Ramos; regionalismo; tradição literária; tradição crítica.

${ }^{*}$ Professora Assistente no Departamento de Letras Modernas da FCL-UNESP-ASSIS, área de Língua e Literatura Italiana, com formação em Teoria Literária e Literatura Comparada na FFLCH-USP e Literatura Brasileira no IEB-USP. 


\begin{abstract}
Starting from the set wherein Vidas Secas (1938) stands out, it is possible to establish parameters that make of Graciliano Ramos' oeuvre the overcoming of realism due to the scope of representation and the quality of formal handling developed by the author, imbibed in the Brazilian and universal literary tradition, and whose result the criticism of Antonio Candido, skilful in taking into account the former critique, points out with precision. Perusing the facts that mark the creation and reception of Vidas Secas (including the production of the movie by Nelson Pereira dos Santos in 1963), the present work is a preamble for analyses that take into account the coherence of Graciliano Ramos with the absorption of expressive resources used by American and European practitioners of a literature engaged in adjusting the expression of contrasts and in reformulating the so-called regionalism.
\end{abstract}

Keywords: Graciliano Ramos; regionalism; literary tradition; criticism tradition.

Toda manhã, bem cedo, abria o pequeno armário de pinho do seu quarto de pensão, tirava lá do fundo a garrafinha de cachaça, tomava um gole em jejum e se sentava na mesa. A paisagem era um longo telhado sujo onde os gatos do Catete se amavam sem vergonha e um pátio de garage onde os motores dos caminhões sempre custavam a pegar. E ali, caneta na mão, fumando cigarro Selma, ia contando devagar, num papel vagabundo, as pobres aventuras da cachorra Baleia.

Rubem Braga

\title{
1. Fortuna regionalista: Antonio Candido e Graciliano Ramos
}

Durante os anos de 1970, Antonio Candido elaborou um raciocínio muito importante para entender as manifestações do regionalismo na literatura brasileira. Partindo das relações entre subdesenvolvimento e cultura, válidas para toda a América Latina, Candido estabelece os seguintes parâmetros: primeiro, durante a fase de "país novo", que corres- 
ponde aos arredores do momento da Independência, a literatura brasileira aproveita o interesse pelo exótico, o respeito pelo grandioso das imagens que reproduzem os recursos naturais exuberantes e a esperança quanto às possibilidades de um país que se realizaria bem no futuro. Assim, a forma literária "compensava o atraso material e a debilidade das instituições por meio da supervalorização dos aspectos regionais, fazendo do exotismo razão de otimismo social" (2006c, p. 170). A idéia de pátria se misturava à idéia de terra, e o Romantismo brasileiro bebeu muito nessa fonte. Em segundo lugar, quando acontece uma mudança de perspectiva, e a literatura passa a revelar os problemas do país - como acontece no chamado romance de 30 -, as grandiosas condições naturais passam a constituir um paradoxo inconcebível em face da debilidade ou da desorganização das instituições. Então, "a visão que resulta é pessimista quanto ao presente e problemática quanto ao futuro" (CANDIDO, 2006c, p. 171).

Segundo o crítico, aquela primeira fase estaria conduzida por uma "consciência amena do atraso", para a qual são decisivos alguns fatores como as influências estrangeiras, que só podem ser examinadas corretamente quando se aborda a questão da dependência cultural como fato natural, dada a condição colonial por que passamos. Outro elemento de peso é a penúria cultural e a insuficiência de público, que fazia os escritores daqui cultivarem padrões europeus "ideais", o que produziu muitos exercícios de mera alienação cultural, uma espécie de "aristocratismo alienador" (CANDIDO, 2006c, p. 179), ao lado de obras válidas, nas quais a assimilação de formas e valores da moda europeia se unia a pontos locais de referência. Ainda assim, nesse caso observa-se um movimento pendular entre realidade e utopia, de cunho ideológico, capaz de justificar a convivência entre analfabetismo e requinte, bem como entre cosmopolitismo e regionalismo, misturados ao esforço de superação da incultura na conquista de uma independência espiritual.

$\mathrm{Na}$ segunda fase, denominada por Candido de "consciência do atraso" (ou do subdesenvolvimento), não há passividade nem euforia no ponto de vista. A visão dos problemas e da catástrofe pode levar a reformulações políticas, pela via artística inclusive. Essa compreensão aparece por volta dos anos de 1930, através da mudança de orientação orquestrada pela ficção regionalista, que abandona o pitoresco em favor da desmistificação do homem rústico brasileiro. A noção de "país subdesenvolvido" substitui a de "país novo". Essa convicção se manifesta claramente após a Segunda Guerra, sobretudo nos anos de 1950, e contribui para matizar as questões envolvidas por atitudes patrióticas. Ao lado disso, Candido considera que "quanto mais o homem livre que pensa se imbui da realidade trágica do subdesenvolvimento, mais ele se imbui da aspiração revolucionária”, ou seja, o homem pode rejeitar "o jugo econômico e político do imperialismo e 
[...] promover em cada país a modificação das estruturas internas, que alimentam a situação de subdesenvolvimento", além de encarar as influências com mais serenidade e objetividade, "como vinculação normal no plano da cultura" (CANDIDO, 2006c, p. 186). Tal postura alia inovação expressiva e capacidade de luta no plano político e econômico.

Duas observações do ensaio ainda precisam ser lembradas. A primeira diz respeito à fase de "pré-consciência do subdesenvolvimento", por volta dos anos de 1930 e 1940, quando tivemos o "regionalismo problemático", ou "romance do Nordeste", como ficou conhecido aqui no Brasil. O romance social se relaciona com aspectos regionais e com algo pitoresco, combinados com certo esquematismo humanitário. José Lins do Rego manifesta esses pontos, ao menos em parte de sua obra, repisando os mesmos temas. Superado o otimismo patriótico, o pessimismo se desvia do homem pobre (que havia sido eleito elemento refratário ao progresso, na etapa de consciência amena) e mostra a sua degradação como consequência da espoliação econômica - não se trata mais de apontar o destino individual, mas de desmascarar a realidade social.

A segunda observação diz respeito ao salto da literatura regionalista sobre a herança urbana na representação. Os melhores produtos da ficção brasileira eram urbanos, tendo Machado de Assis como maior representante, num esforço de transcendência do pitoresco em obras requintadas. Com a ficção de 1930, as tendências regionalistas são transfiguradas pelo realismo social e, numa etapa seguinte, são ultrapassadas - o que faz o qualificativo "regionalista" perder o sentido. A dimensão regional continua presente nas obras, porém sem constituir requisito de consciência. Somente essa superação pôde produzir o refinamento técnico de Graciliano Ramos. A partir de sua obra, a nossa literatura está apta a valorizar o pitoresco na medida do equilíbrio justo com a universalidade, e até mais que isso: são produzidas obras que incorporam elementos textuais caracterizadores de uma terceira fase de consciência, que Antonio Candido chama de "super-regionalista", ou "consciência dilacerada do subdesenvolvimento", da qual é tributária a obra de Guimarães Rosa, plantada numa universalidade do regional (2006c, p. 195).

No ano de 1945, Graciliano Ramos publicava Infância e Antonio Candido era crítico titular no Diário de São Paulo. Aproveitando o destaque do escritor alagoano em meio aos chamados "romancistas do Nordeste", Candido escreveu cinco artigos para o jornal, um para cada livro de Graciliano até aquela altura. A recepção do escritor foi sensível e amistosa, dando início a uma relação bastante amigável entre crítico e artista. Para a primeira edição póstuma da obra completa de Graciliano, atendendo ao desejo que o escritor havia manifestado à editora José Olympio, Candido escreveu uma introdução 
para o primeiro volume da coleção, Caetés. Para isso, refundiu os cinco artigos anteriores, acrescentando uma análise de Memórias do Cárcere e uma conclusão, compondo assim o ensaio "Ficção e confissão", editado pela José Olympio também num opúsculo (uma raridade bibliográfica, provavelmente) e tempos depois deslocado para o volume São Bernardo, até desaparecer de circulação nos anos 1970. Somente no centenário de Graciliano preparou-se um volume que reeditou o célebre ensaio com outros, em clima comemorativo que, segundo o crítico, servia para manifestar seu "constante apreço por um dos maiores escritores da nossa literatura, um dos raros cuja alta qualidade parece crescer à medida que o relemos" (CANDIDO, 2006e, p. 13).

Ao Fiç̧ão e confissáo se juntam, no volume de 1992 da editora 34, reeditado pela Ouro sobre Azul, Os bichos do subterrâneo, escrito em 1959 para a coleção Nossos Clássicos da Agir, reeditado na coletânea Tese e antítese e considerado pelo crítico como um ensaio complementar ao Ficção e confissão, sobretudo porque revê a posição "insuficiente" assumida em face de Angústia. Ainda temos, no volume que leva o título do primeiro ensaio, No aparecimento de Caetés, texto de uma palestra realizada no cinquentenário da publicação do primeiro romance de Graciliano; e Cinquenta anos de Vidas Secas, artigo solicitado por Nilo Scalzo no final dos anos de 1980, para o suplemento Cultura do Estado de S. Paulo.

Para falar de Vidas Secas, no ensaio mais recente Antonio Candido parte de observações de Otto Maria Carpeaux e Lúcia Miguel Pereira. Do primeiro, aproveita o que o crítico austríaco recupera de Aurélio Buarque de Holanda a respeito da renovação de Graciliano sobre cada romance que produziu - ou seja, cada obra passa a ser um tipo diferente de romance, ao contrário da repetição ou retomada dos mesmos temas, fato observado nos contemporâneos. Assim, a cada experiência era como se o escritor destruísse "a forma para recomeçar adiante" (CANDIDO, 2006a, p. 143). Esse procedimento era parte de um plano de trabalho disposto a dizer o essencial, obsessivamente insatisfeito com os excessos, conforme observa Candido. E, se os três primeiros romances seguem esses movimentos de depuração da forma, Vidas Secas pode ser visto como representante do ápice desse método. $\mathrm{Na}$ verdade, se observamos atentamente o conjunto da obra, o significado do livro supera a originalidade da forma, pois seria o último romance de Graciliano, que preferiu as memórias a partir de Infância.

A história da família de retirantes vem diferente de Caetés, São Bernardo e Angústia porque não é escrita em primeira pessoa e, portanto, não se organiza em torno de um único protagonista a centralizar as forças da trama. Além disso, Vidas Secas não se apresenta através de uma composição contínua, pois os capítulos permitem leituras isoladas, fazendo jus às publicações anteriores de partes autônomas, como "uma série de quadros" 
(PEREIRA, 2005, p. 150 apud CANDIDO, 2006a, p. 145), diz o crítico, recorrendo a uma observação feita à época da saída do romance por Lúcia Miguel Pereira no excelente Boletim de Ariel, da editora de mesmo nome, dirigido por Agripino Grieco e Gastão Cruls. Da mesma resenha, que perguntava se o livro poderia ser classificado como romance, por ser muito breve, Antonio Candido também aproveita o destaque oferecido à capacidade de Graciliano de ressaltar a humanidade das criaturas mais embrutecidas pelo meio que vivem, de dar voz aos que não podem se analisar, impondo uma limitação à narrativa e testando minuciosamente os parcos recursos expressivos. Se para Lúcia Miguel Pereira o último romance de Graciliano não deveria ser visto dentro das categorias da moda daquele tempo, a excelência em relação ao realismo e à literatura empenhada é "devida a uma capacidade de generalização que engloba e transcende estas dimensões" (CANDIDO, 2006a, p. 147), perfazendo a expressão de uma condição humana, não apenas de uma região ou classe social.

O ensaio de Antonio Candido continua a retomar "resenhas esquecidas", retirando duas notas de Almir de Andrade em texto ligeiramente posterior ao de Miguel Pereira. A primeira observação remete ao alcance crítico daquele momento de 1938, medido pelo papel desempenhado pelo romance no Brasil ao aprofundar-se nos problemas. Almir de Andrade distingue a abordagem em grandes quadros comumente utilizada pelos romances do Nordeste do procedimento empregado por Graciliano em Vidas Secas, capaz de esquadrinhar a miséria, a opressão e o sofrimento. A segunda nota interessante da resenha compara a saga de Fabiano à de Luís da Silva em Angústia, com critérios muito conservadores, ligados às formas de análise psicológica e, portanto, privilegiando a continuidade e fluidez do romance de 1936. A resenha de Lúcia Miguel Pereira percebeu melhor a originalidade e o grau de dificuldade da escrita de Vidas Secas. Além disso, conforme assinala Antonio Candido, revela o paradoxo entre a riqueza interior das personagens e as "vidas culturalmente pobres" (CANDIDO, 2006a, p. 149). A originalidade da ensaísta está na aceitação da legitimidade da forma descontínua, da brevidade da extensão e da interioridade dos seres, o que, segundo Antonio Candido, se desprende de uma análise canônica para afirmar que o romance e sua visão social criaram uma visão dramática que perpassa todos os níveis da composição, ressaltando o mundo opressivo que representam.

Conforme se percebe, as considerações inspiradoras de Antonio Candido têm uma base sólida na crítica anterior: são capazes de rever a tradição de análises para dissecar a obra literária com olhos atentos para a composição e para suas transformações ao longo do tempo, visão que ganha amplitude e maturidade ao considerar todos os achados, inclusive os que permaneceram datados. Ao mesmo tempo, é possível confrontar 
certas afirmações, como as de Álvaro Lins publicadas em 1947. A despeito da competência do estudo, este crítico sustenta a opinião de que os capítulos independentes de Vidas Secas, sem articulação firme e segura, formam peças autônomas de valor literário indiscutível. Além disso, segundo a mesma análise, o "excesso de introspeç̧ão em personagens tão primários e rústicos" contribui para a inverossimilhança do texto, por causa da técnica empregada - "se houvesse maior proporção entre episódios e monólogos, entre a vida exterior e interior das personagens, este problema da ficção teria sido resolvido de maneira perfeita" (LINS, 1986, p. 152).

Embora pontuado de boas observações sobre a obra de Graciliano, nota-se ali certo conservadorismo, quando Lins assinala a falta de articulação entre os capítulos de Vidas Secas. Além disso, recorremos à técnica referida pelo crítico para argumentar que não há propriamente introspecção nem "monólogo interior", conforme Álvaro Lins chega a comentar. Para Antonio Candido, nos romances em primeira pessoa Graciliano se serve do devaneio como recurso narrativo para equilibrar internamente os protagonistas, "permitindo elaborar situações fictícias que compensam as frustrações da realidade” (2006b, p. 26). É ainda Candido que situa Angústia como a evolução do devaneio para "crispado monólogo interior" cuja introjeção deforma "o espírito e as coisas" (CANDIDO, 2006b, p. 27).

Coerente ao extremo, Graciliano preferiu explorar o interior dos personagens em Vidas Secas sem permitir que eles se expressassem, razão pela qual o foco foi deslocado. Nesse sentido, o estilo indireto livre é o instrumento preferido em diversas passagens, compostas com a intenção de fazer prevalecer a autoria e, portanto, memoráveis devido à resistência e ao fracasso das pessoas ao ambiente rústico (bastante conhecido pelo autor, nascido no que se chamava "Polígono das secas"), conforme veremos adiante.

Antonio Candido ressalta que seu Ficção e confissão envelheceu, e que a crítica desde os anos quarenta fez aparecer estudos "mais de acordo com o gosto do dia". Todavia, o próprio crítico aponta a atualidade do seu pressuposto básico, dizendo que "ainda lhe parece justo" (CANDIDO, 2006e, p. 14). Esse pressuposto é a passagem da ficção para a autobiografia logo após Vidas Secas como desdobramento coerente e necessário da obra de Graciliano. Ao atualizar o ensaio para a época de comemoração do centenário de Graciliano, não parecia adequado considerar as duas fases do autor no mesmo nível literário. Para o crítico, Infância, ainda com o peso de ficção, é superior a Memórias do Cárcere, o livro puramente autobiográfico, apesar de seu valor como documento humano.

Esquadrinhar a fortuna crítica de Graciliano Ramos é praticamente impossível, dado o seu volume e as diferentes linhas de interpretação, favorecidas pela habilidade da obra ao ter percorrido uma vastidão de ambientes 
(da fazenda à cidade, da casa à prisão) e tipos humanos (de vaqueiros a fazendeiros, de empregados a patrões, de vagabundos a políticos). De qualquer modo, vale recuperar parte da tradição com os ensaios aqui mencionados, tendo em vista a importância que suas observações argutas podem ter para fecundar novas abordagens. À parte um saudosismo editorial, é agradável perceber que a divulgação das primeiras aproximações à obra do escritor alagoano contava com ensaios de Otto Maria Carpeaux, Álvaro Lins, Antonio Candido e João Luiz Lafetá anexados aos romances.

\section{MEDo DE ENCHER LINGUIÇA}

Sabe-se que Graciliano Ramos era perfeccionista. De alguns depoimentos de amigos e do próprio escritor alagoano deduz-se a impaciência com a retórica e com a eloquência. Oswaldo Alves mostra a opinião decisiva de Graciliano:

Quando se trata da sua obra assume atitude excessivamente modesta, fazendo sérias restrições, ou decisivamente ousada, elogiando-a. Por exemplo: se exaltamos seus livros ou perguntamos entusiasmados quando vai aparecer um novo romance, ele responde quase com raiva: "Nunca mais. Eu já dei o que tinha que dar - não escrevo mais!” E se discordamos, Graciliano diz agressivo: "Oh! gente! eu sou uma besta! Vocês ainda não se convenceram disto?" Mas se alguém se lembra de falar em estilo, em escrever bem, ele afirma com a maior naturalidade deste mundo: "Eu sou dos poucos escritores que sabem escrever neste país. Eu conheço a língua, ora esta!" E conhece mesmo. Ninguém poderia tomá-lo por pretensioso ao ouvir isto. Ele fala com um tom de absoluta sinceridade e com a maior simplicidade. Não é cabotinismo. (ALVES, 1946, p. 9).

Para organizar obra e vida numa linha temporal, os romances de Graciliano aparecem na seguinte ordem: Caetés é de 1933, São Bernardo, de 1934, Angústia, de 1936, Vidas Secas, de 1938, Infância, de 1945 e Memórias do Cárcere é o livro póstumo, de 1953. São todos livros produzidos na maturidade, pois Graciliano já passava dos quarenta anos. Havia começado a trabalhar em Caetés por volta de 1925; em março de 1936 ele é preso, e Angústia sai sem revisão, em agosto desse ano. Os livros saem com certa regularidade - os intervalos são de um e dois anos, espaçados entre 1938 e 1945. Nesse período, Graciliano foi nomeado Inspetor Federal de Ensino Secundário, no Rio de Janeiro e, em 1944, publica os contos Histórias de Alexandre. Os de Insônia saem em 1947. O autor morreu em 1953, em março. Depois de Memórias do Cárcere, saem, em 1954, Viagem (Checoslováquia - 
URSS); em 1962, Linhas Tortas, Viventes das Alagoas e Alexandre e outros heróis. Em 1980 sai publicada a sua correspondência.

Graciliano escreveu durante um momento próspero para a literatura no Brasil, período localizado entre as décadas de 1920 e 1960, forçando os extremos de modo a aproveitar as atualizações do que havia se esboçado nos anos de 1920 em termos de aceitação das inovações formais e temáticas. Quando Graciliano começa a produzir sua obra, o país havia recentemente mudado bastante e a literatura se preparava para viver o que talvez tenha sido o seu período mais significativo, pois, graças à incorporação das novidades em nível específico, alterando a fisionomia da obra, e em nível genérico, rejeitando velhos padrões, "o inconformismo e o anticonvencionalismo se tornaram um direito, não uma transgressão" (CANDIDO, 2006, p. 225). Noutras palavras, a libertação assegurada pelo modernismo permitiu a aceitação de formas despojadas que não necessariamente aproveitaram a herança modernista.

Houve ainda o interesse pelas correntes de esquerda, o êxito da Aliança Nacional Libertadora "e certo espírito genérico de radicalismo, que provocou as repressões posteriores ao levante de 1935 e serviu como uma das justificativas do golpe de 1937" (CANDIDO, 2006, p. 228). A repercussão do marxismo pôde ser vista em ensaios e na ficção, e vários intelectuais e escritores atuaram declaradamente à esquerda (como é o caso de Graciliano), além dos simpatizantes e dos que apenas manifestaram uma consciência social. o clima geral se refletiu em muitas produções dirigidas aos renovados estudos brasileiros, desde coleções como a Brasiliana e Documentos Brasileiros, até análises individuais, como Casa Grande e Senzala (1933), de Gilberto Freyre, Raizes do Brasil (1935), de Sérgio Buarque de Holanda e Formação do Brasil Contemporâneo (1942), de Caio Prado Júnior, todos acompanhando a fundação recente de cursos superiores de filosofia, ciências sociais, história e letras, com a contribuição de professores estrangeiros.

Graciliano situa-se como autor no tempo que também favoreceu a divulgação do livro (graças ao alcance das editoras e sua transformação em instituições sólidas) e privilegiou a prosa de ficção mais acessível, não tão hermética como a prosa dos anos de 1920. Mas talvez o maior benefício da literatura escrita após 1930 tenha sido o conhecimento sobre o Brasil que ela proporcionou. Assim, a leitura de romances do Nordeste poderia trazer aos leitores das regiões mais ao sul do país a noção de um modo de vida diferente, assim como as classes mais cultas puderam se aproximar de representações da vida carente de recursos básicos de sobrevivência e precisada de igualdade de direitos, do mesmo modo como o leitor urbano pôde perceber a vida do interior, dos centros menores e do meio rural. Nada mais coerente para o romance brasileiro, que nasce no século XIX com essa 
missão de descoberta, conforme nos ensinou Antonio Candido. Toda uma geração de leitores teve nos anos de 1930 um contato maior com o território e a raça brasileiros através dos romances, tornando possível a conscientização e a radicalização acerca do Brasil esquecido e espoliado pelas oligarquias. Para Antonio Candido,

[...] depois de 1930 se esboçou uma mentalidade mais democrática a respeito da cultura, que começou a ser vista, pelo menos em tese, como direito de todos, contrastando com a visão de tipo aristocrático que sempre havia predominado no Brasil, com uma tranqüilidade de consciência que não perturbava a paz de espírito de quase ninguém. Para esta visão tradicional, as formas elevadas de cultura erudita eram destinadas apenas às elites, como equipamento (que se transformava em direito) para a "missão" que lhes competia, em lugar do povo e em seu nome. O novo modo de ver, mesmo discretamente manifestado, pressupunha uma "desaristocratização" (com perdão da má palavra) e tinha aspectos radicais que não cessariam de se reforçar até nossos dias, desvendando cada vez mais as contradições entre as formulações idealistas da cultura e a terrível realidade da sua fruição ultra-restrita. Por extensão, houve maior consciência a respeito das contradições da própria sociedade, podendo-se dizer que sob este aspecto os anos 30 abrem a fase moderna nas concepções de cultura no Brasil. (CANDIDO, 2006, p. 235).

A nova visão de realidade trazia nos romances novos procedimentos. Desde as capas, ilustradas por artistas como Santa Rosa, atestando a permanência das linhas modernistas, a assimilação de uma herança artística brasileira se faz presente. Ao lado de Graciliano Ramos, Jorge Amado, José Lins do Rego e Raquel de Queirós são os nomes mais conhecidos entre os romancistas que apareceram naqueles anos. Havia muitos outros, todos envolvidos na proposta de revelar, quase como um levantamento minucioso dividido por setores sócio-econômicos, uma realidade social pouco mostrada até o momento:

Foi com efeito notável a interpenetração literária em todo o Brasil depois de 30, quando um jovem, digamos do interior de Minas, ia vivendo numa experiência feérica e real a Bahia de Jorge Amado, a Paraíba ou o Recife de José Lins do Rego, a Aracaju de Amando Fontes, a Amazônia de Abguar Bastos, a Belo Horizonte de Ciro dos Anjos, a Porto Alegre de Érico Veríssimo ou Dionélio Machado, a cidade cujo rio imitava o Reno, de Viana Moog. Foi como se a literatura tivesse desenvolvido para o leitor uma visão renovada, 
não-convencional, do seu país, visto como um conjunto diversificado mas solidário. (CANDIDO, 2006, p. 226-227).

No caso de Graciliano Ramos, a etiqueta "regionalismo" (que se deve em parte ao simples distanciamento geográfico da capital, Rio de Janeiro, centro intelectual e base das avaliações literárias) só se aplica parcialmente, prova de que a consciência supera a classificação, conforme ficou dito. A rigor, somente Vidas Secas é regionalista. O romance publicado em 1938 narra a vida de uma família de vaqueiros reduzida ao mínimo possível para a sobrevivência, com a linguagem admirável, reduzida também ao mínimo, que parece espelhar a humanidade espoliada das personagens, privadas até da voz na narrativa. Ao retirar a força da condução de uma primeira pessoa e a firmeza de um ponto de vista a conduzir a narrativa, podemos dizer, ao contrário do que afirmara Álvaro Lins, que Graciliano opera uma espécie de sonegação da palavra, pois nenhuma personagem recebe o privilégio de narrar (dádiva talvez tão alta quanto dormir numa cama de couro, como sonhava Sinhá Vitória...).

A consciência estética de Graciliano o fazia perseguir seu próprio estilo, emendando, substituindo, mudando a sintaxe, enfim, reescrevendo à caça da expressão mais justa, rejeitando assim os supérfluos da linguagem e evitando os termos imprecisos. O filho de Graciliano, Ricardo Ramos, reproduz diálogos com o pai:

- Não escreva "algo" - ele implicou.

Quis saber por quê, me respondeu:

- É crime confesso de imprecisão.

Mais tarde eu estranhei:

- Por que você não usa nunca reticências e exclamações?

Não demorou um segundo:

- Reticências, porque é melhor dizer do que deixar em suspenso. Exclamações, porque não sou idiota para viver me espantando à toa. E certa vez, a propósito de um parágrafo em que eu empregara diferentes tempos de um verbo (passado, presente, futuro), recomendou:

- Não faça isso.

Resisti, Machado de Assis fazia, até numa frase. Estava certo. Era um erro, sim. Não gramatical, mas de pensamento. Ninguém raciocina aos pulos. E arrematou:

- O importante é escrever duas páginas no condicional sem ficar monocórdio, nem dar eco, sem que ninguém perceba. (RAMOS, 2011, p. 84). 
E, para descrever um procedimento muito comum com os originais:

Sempre encurtados, nunca aumentados, pois tendia ao concentrado e não ao derrame. Pelas margens, nada. O essencial das mudanças nas entrelinhas. A datilografia posterior e alheia (em casa ou profissional) era um trabalho só de atenção. Que em seguida ele revia, suprimindo, podando, sofrendo ainda (RAMOS, 2011, p. 142).

Antonio Candido destaca os pressupostos, e utiliza a expressão popular para definir a fraqueza - ou o horror - de Graciliano, bem como assinala o fascínio - ou a tentação:

Esse medo de encher linguiça é um dos motivos da sua eminência, de escritor que só dizia o essencial e, quanto ao resto, preferia o silêncio. O silêncio devia ser para ele uma espécie de obsessão, tanto assim que quando corrigia ou retocava os seus textos nunca aumentava, só cortava, cortava sempre, numa espécie de fascinação abissal pelo nada - o nada do qual extraíra a sua matéria, isto é, as palavras que inventam as coisas, e ao qual parecia querer voltar nessa correção- destruição de quem nunca estava satisfeito. (CANDIDO, 2006a, p. 144)

Finalmente, a explicação de Graciliano reproduzida por Joel Silveira é, ao mesmo tempo, poética e impecável:

Falava-se do ofício de escrever, ele disse:

- Quem escreve deve ter todo o cuidado para a coisa não sair molhada.

Também não entendi. Ele explicou:

- Quero dizer que da página que foi escrita não deve pingar nenhuma palavra, a não ser as desnecessárias. É como pano lavado que se estira no varal.

E prosseguiu - naquela manhã estava de língua solta:

- Deve-se escrever da mesma maneira como as lavadeiras lá de Alagoas fazem seu ofício. Sabe como elas fazem?

- Não.

- Elas começam com uma primeira lavada. Molham a roupa suja na beira da lagoa ou do riacho, torcem o pano, molham-no novamente, voltam a torcer. Depois colocam o anil, ensaboam, e torcem uma, duas vezes. Depois enxaguam, dão mais uma molhada, agora jogando a água com a mão. Depois batem o pano na laje ou na pedra limpa e dão mais uma torcida e mais outra, torcem até não pingar do pano uma só gota. Somente depois de feito tudo isso é que elas dependuram a roupa lavada na corda ou no varal, para 
secar. Pois quem se mete a escrever devia fazer a mesma coisa. A palavra não foi feita para enfeitar, brilhar como ouro falso, a palavra foi feita para dizer (SILVEIRA, 1998, p. 284).

\section{A dor de escavar Graciliano}

Quase como compensação pela escassez presente em vários níveis e perceptível à leitura, o romance ganha tecnicamente com a utilização do discurso indireto, sob o qual é narrado em sua maior parte, com a disposição de desvendar a mente das personagens que não podem se inventariar, permanecendo submetidas ao silêncio e ao universo interior. Não seria verossímil colocar aquelas pessoas em monólogos que atestassem sua dicção ou sua capacidade de digressão, coisas que estão longe das condições daquela gente. Por outro lado, temos exemplos interessantes nas cenas protagonizadas pela cachorra Baleia:

Baleia assustou-se. Que faziam aqueles animais soltos de noite? A obrigação dela era levantar-se, conduzi-los ao bebedouro. Franziu as ventas, procurando distinguir os meninos. Estranhou a ausência deles.

Não se lembrava de Fabiano. Tinha havido um desastre, mas Baleia não atribuía a esse desastre a impotência em que se achava nem percebia que estava livre de responsabilidades. Uma angústia apertou-lhe o pequeno coração. Precisava vigiar as cabras: àquela hora cheiros de suçuarana deviam andar pelas ribanceiras, rondar, as moitas afastadas. Felizmente os meninos dormiam na esteira, por baixo do caritó onde sinhá Vitória guardava o cachimbo.

Uma noite de inverno, gelada e nevoenta, cercava a criaturinha. Silêncio completo, nenhum sinal de vida nos arredores. O galo velho não cantava no poleiro, nem Fabiano roncava na cama de varas. Estes sons não interessavam Baleia, mas quando o galo batia as asas e Fabiano se virava, emanações familiares revelavam-lhe a presença deles. Agora parecia que a fazenda se tinha despovoado. Baleia respirava depressa, a boca aberta, os queixos desgovernados, a língua pendente e insensível. Não sabia o que tinha sucedido. o estrondo, a pancada que recebera no quarto e a viagem difícil do barreiro ao fim do pátio desvaneciam-se no seu espírito. (RAMOS, 1986, p. 89-90).

Se as pessoas desse romance não conseguem pensar ou, quando pensam, não sabem expressar o que pensam, o narrador explora essa condição através de seu discurso. Declara Graciliano em sua correspondência, quando já havia escrito algumas passagens de Vidas Secas: "Nenhuma de- 
las tem movimento, há indivíduos parados. Tento saber o que eles têm por dentro" (RAMOS, 1982, p. 201). Fabiano, segundo o narrador, por exemplo, deduz que as palavras são perigosas, e talvez seja melhor grunhir para se entender com os bichos. No caso de Baleia, a personagem não pensa, de fato, e não pode expressar sensações ou raciocínios humanos, então o narrador se intromete e imagina o que pode ter acontecido ao animal. A mesma personagem é responsável por outra inovação de Graciliano, agora no âmbito do conteúdo. Baleia (cujo nome, conforme observação rebatida em várias aulas de colégio, remete quase ironicamente a um ambiente muito diverso da secura em que se passa a história) sintetiza a rudeza e a solidariedade possível naquele meio - o animal que se esforça para sobreviver é, ao mesmo tempo, o personagem grandioso na trama. Assim como não se arrepende de ter devorado partes do amigo papagaio, pela necessidade do início da viagem, a cachorra mostra-se fiel à família quando caça o preá e entrega a presa aos cuidados humanos, "sabendo" que só lhe restarão os ossos e o couro da caça. Assim, o compromisso inesperado para aquele universo rústico e depauperado, inclusive de sentimentos, aparece em cenas inesquecíveis.

Esse tipo de abordagem constituía novidade para os romances de Graciliano, como também não havia aparecido ainda a narrativa hábil em nivelar o ser humano ao animal, a ponto de causar certa inversão de referenciais. Vale lembrar que o episódio da morte de Baleia, em parte reproduzido acima, é um dos primeiros fragmentos de Vidas Secas escrito pelo autor, é um dos pontos de partida do livro, conforme carta de Graciliano à esposa: "[...] como você vê: procurei adivinhar o que se passa na alma duma cachorra. [...] É a quarta história feita aqui na pensão" (RAMOS, 1982, p. 201).

Em 1938, sob o impacto da publicação do romance, Rubem Braga escreve algumas das mais significativas observações sobre a composição de Vidas Secas. Tendo convivido com Graciliano, dividindo as mesmas dificuldades de pensão, Braga refaz o percurso do livro, desde o quarto e a situação da criação até a descrição do estilo "funcional" e, mais que isso, "eficiente" (BRAGA, 2001, p. 128). Explica a autonomia dos capítulos reforçando que não se tratava de "recreação literária", mas de "necessidade financeira": o "romance desmontável" inventado por Graciliano teria a estrutura condicionada pela situação difícil (BRAGA, 2001, p. 127). Contudo, é no equilíbrio de Vidas Secas que reside sua maior importância - para Rubem Braga, a história interna e a história externa de Fabiano e sua família são capazes de amarrar todos os aspectos da narrativa. Noutras palavras, sem sair de dentro da família o texto nos conta como a paisagem rege a vida das pessoas, como a sociedade as explora e humilha, como é difícil pensar sob essas condições.

Assim como Vidas Secas de Graciliano é, essencialmente, o auge da "força criadora de um estilo parcimonioso que parece estar no limite da 
expressão possível - em contraste com a caudalosa falação de tantos romances daquela hora" (CANDIDO, 2006a, p. 146), o filme de Nelson Pereira dos Santos (1963) elimina diálogos, cores, trilha sonora, ligações entre as sequências, tratamento de luz, entre tantos recursos que faziam do cinema dos anos de 1960 um campo vasto de experimentações - basta lembrar que $81 / 2$ (Federico Fellini, 1960) é do mesmo ano de Vidas Secas. Comparar o romance a uma série de gravuras entalhadas na madeira, como havia feito Lúcia Miguel Pereira, é procedimento mais acertado do que estabelecer relações com a fotografia, se levarmos em conta a rusticidade, o caráter artesanal, as dificuldades e o resultado, cuja visualização parece ser determinada para além do bidimensional, permitindo que se perceba o esforço empenhado na obra.

Do mesmo modo, o filme se abstém do caráter de documentário realista e se priva de recursos quando a fotografia retira os filtros da câmera e deixa a luz "entalhar" a imagem. Temos a sequência do empenho de Graciliano ao cortar palavras, excessos, para manter uma ossatura de romance. Nelson Pereira conseguiu equilibrar os recursos do audiovisual de que dispunha com o processo de criação literária, como se aquele servisse de instrumento para a escavação deste. Graças à adaptação do romance para o cinema, hoje podemos nos utilizar do filme para explorar a força da história de Graciliano, bem como da profundidade da dor de suas personagens.

Se o grau de realidade do romance se dá devido às imagens verbais que constroem uma ordem que não é a realidade, mas que segue uma lógica verbal, o texto cria uma realidade própria. No filme, a mesma história que servira à palavra passa a servir à imagem: assim como não é realidade materializada pela câmera, as cenas revelam aspectos da realidade possíveis somente no âmbito da imagem. Nos dois casos, tira-se proveito do instrumento ao máximo - contudo, não se observam excessos. As contidas descrições de Graciliano transformam-se em imagens cuidadosamente medidas pelo diretor. Para José Carlos Avellar, que acredita na narrativa de Graciliano como algo que "pode ser lido como se o autor estivesse contando um filme que viu" (AVELLAR, 2007, p. 47) e, ao mesmo tempo, na independência entre texto e filme,

O texto é um estímulo para a imaginação e não para uma reconstituição de imagens verbais tal e qual em imagens visuais. Não se trata de ilustrar o que está escrito nem de ilustrar o modo de escrever, mas de voltar ao que o escritor viu (como se a imaginação fosse um filme), ao processo que o levou a escrever seu texto. (AVELLAR, 2007, p. 46). 
No tocante ao conteúdo, por sua vez, o filme segue à risca o pressuposto do romance, deixando de lado a questão da seca para se deter sobre problemas advindos da questão agrária, como o deslocamento humano. A ênfase do livro sobre a propriedade (ou a falta dela, no caso da família de Fabiano) e sobre as relações de trabalho (que pautam as relações sociais) é ampliada pelo filme.

Para Jean Claude Bernardet, "o filme é uma dolorosa meditação sobre as possibilidades de vir a ser homem no Brasil" (BERNARDET, 1967, p. 61). Fabiano chefia uma família com formato de classe média: pai, mãe, dois filhos, cachorro e papagaio. Esse pai é modelo para os meninos (há uma cena longa com um dos filhos imitando Fabiano na lida). A mãe tenta resolver problemas emotivos, faz contas, cuida das tarefas domésticas, sonha. Mesmo refletindo na organização e nas relações um modelo que tanto pode ser de classe média quanto sertanejo, a família de Fabiano tem ação reduzida à obtenção de meios de sobrevivência, incluindo atos extremos e ausência de comunicação - quando falam, é para desabafo individual, não para uma conversa entre si. Quando Fabiano reage, em cenas que se distinguem pelo maior teor de abstração na adaptação de Nelson Pereira, manifesta o que Jean Claude chamou de "núcleo de dignidade":

Esse núcleo de dignidade é colocado em situação duas vezes no filme. [...] Saindo da aldeia, no caminho de casa, Fabiano encontra os cangaceiros, com um dos quais esteve na cadeia. A estrada bifurca, os cangaceiros vão seguindo um caminho, Sinhá Vitória e as crianças já enveredaram pelo outro; Fabiano, no cavalo que lhe emprestara um cangaceiro, e olhando para a espingarda, hesita na encruzilhada: continuar ou revoltar-se? Fabiano toma o rumo de casa. Essa cena se desenvolverá mais tarde: Fabiano, armado de um facão, depara com o soldado provocador, perdido no mato. Nesse encontro de homem para homem, de inimigo para inimigo, de novo Fabiano hesitará, e o soldado terá medo. Nada acontecerá, mas é uma porta aberta para o futuro. $O$ filme não vai além dessa expectativa. (BERNARDET, 1967, p. 64).

Se o Fabiano de Nelson Pereira pode ser qualquer um de nós, dado o alcance das cenas descritas, ele simboliza o homem que mesmo esmagado em qualquer condição pode ostentar um direito maior que o da revolta, o da qualidade moral, o estado respeitável. Ele representa um complemento justo ao Fabiano do romance, quando se pensa sobretudo no fato de o filme ter sido realizado por um "homem da cidade", ampliando a perspectiva do drama da história criada por Graciliano Ramos, sem deturpar a busca pela clareza da expressão, a violência manifestada como representante das rela- 
ções humanas (violência psicológica, violência física e violência de classe) e o "franciscanismo voluntário da escrita", nas palavras de Benedito Nunes (2003).

Graciliano abominava a vanguarda em geral, incluindo o Modernismo brasileiro. Sua formação se deu essencialmente sobre a leitura dos grandes autores do passado. Era inflexível quanto à correção da escrita, quanto à norma. Paradoxalmente, é possível falar em modernidade do seu texto se nos voltarmos para o refinamento da tradição e para a capacidade de reduzir o real às suas linhas essenciais, contrariando o "culto da forma" e as elegâncias acadêmicas. Esse procedimento já existe em Caetés, o primeiro romance, que também mostra uma amargura cujo pessimismo é em parte corrigido pela retidão que parece existir como meta final. Aliás, parece ser essa mesma meta a pautar a visão de homem do autor - era o que ele parecia procurar sem descanso, na vida e na arte. A "dolorosa meditação" que Graciliano expressa através dos modos de composição de sua ficção se reproduz no doloroso processo da leitura e interpretação da obra, tanto mais grave quanto mais até os ossos nos atinge.

\section{REFERÊNCIAS}

ALVES, Oswaldo. Eles sem máscara: Graciliano Ramos e Marques Rebelo. Leitura, Rio de Janeiro, ano IV, n. 41, p. 9, jul. 1946.

AVELLAR, José Carlos. O chão da palavra. Rio de Janeiro: Rocco, 2007.

BERNARDET, Jean-Claude. Os impasses da ambiguidade. In: . Brasil em tempo de cinema. Rio de Janeiro: Civilização Brasileira, 1967, p. 61-66.

BRAGA, Rubem. Vidas Secas. Teresa. São Paulo, n. 2, p. 126-128, 2001.

CANDIDO, Antonio. A Revolução de 1930 e a cultura. In: Rio de Janeiro: Ouro sobre Azul, 2006, p. 219-240. . A educação pela noite. 5 . ed.

CANDIDO, Antonio. Cinquenta anos de Vidas Secas. In: Janeiro: Ouro sobre Azul, 2006a, p. 143-151.

CANDIDO, Antonio. Ficção e confissão. In: sobre Azul, 2006b, p. 17-99.

. Ficção e confissão. 3. ed. Rio de Janeiro: Ouro

CANDIDO, Antonio. Literatura e subdesenvolvimento. In: . A educação pela noite. 5 . ed. Rio de Janeiro: Ouro sobre Azul, 2006c, p. 169-196.

CANDIDO, Antonio. No aparecimento de Caetés. In: Graciliano Ramos. Rio de Janeiro: Ouro sobre Azul, $\overline{2006 d, ~ p . ~ 92-101 . ~}$

CANDIDO, Antonio. Prefácio. In: . Fiç̧ão e confissão. 3. ed. Rio de Janeiro: Ouro sobre Azul, 2006e, p. 9-15. 
CARPEAUX, Otto Maria. Visão de Graciliano Ramos. In: . Origens e fins. Rio de Janeiro: CEB, 1943, p. 339-351.

LAFETÁ, João Luiz. O mundo à revelia. In: RAMOS, Graciliano. São Bernardo. 43. ed. Rio de Janeiro: Record, 1985, p. 189-213.

LINS, Álvaro. Valores e misérias das Vidas Secas. In: RAMOS, Graciliano. Vidas Secas. 58. ed. Rio de Janeiro, Record, 1986, p. 127-155.

NUNES, Benedito. No limite da transcendência. Folha de São Paulo, 9 mar. 2003. Entrevista. Disponível em: <http://www1.folha.uol.com.br/fsp/mais/fs0903200307.htm >. Acesso em: 20 jan. 2012.

PEREIRA, Lúcia Miguel. A leitora e seus personagens. 2. ed. Rio de Janeiro: Grafia, 2005, p. 150-151.

RAMOS, Graciliano. Cartas. 3. ed. Rio de Janeiro: Record, 1982.

Vidas Secas. 58. ed. Rio de Janeiro: Record, 1986.

RAMOS, Ricardo. Graciliano: retrato fragmentado. 2. ed. São Paulo: Globo, 2011.

. Lembrança de Graciliano. In: GARBUGLIO, José Carlos; BOSI, Alfredo; FACIOLI, Valentim (Org.). Graciliano Ramos. São Paulo: Ática, 1987. p. 11-21.

SCHMIDT, Augusto Frederico (org.). Homenagem a Graciliano Ramos. Rio de Janeiro: Alba, 1943, p. 118-124.

SILVEIRA, Joel. Na fogueira: memórias. Rio de Janeiro: Mauad, 1998.

VIDAS secas. Direção de: Nelson Pereira dos Santos. Alagoas: 1963. 1 filme (103 min.), sonoro, $\mathrm{p} \& \mathrm{~b}$.

Submetido em: 16/11/2012

Aceito em: 24/03/2014 